\title{
ОЦІНЮВАННЯ ТРАНЗИТНИХ МОЖЛИВОСТЕЙ УКРАЇНИ В СВITОВОМУ ЕКОНОМІЧНОМУ ПРОСТОРІ
}

\section{ОЦЕНКА ТРАНЗИТНЫХ ВОЗМОЖНОСТЕЙ УКРАИНЫ В МИРОВОМ ЭКОНОМИЧЕСКОМ ПРОСТРАНСТВЕ}

\section{EVALUATION OF UKRAINE TRANSIT OPPORTUNITIES IN THE WORLD ECONOMY}

Метою статті є комплексне дослідження процесів формування ринку транзитних перевезень Украӥни. Стаття охоплює теоретико-методологічні аспекти становлення та розвитку потенціалу транспортних транзитних вантажоперевезень України. У статті розглянуто теоретичні аспекти формування світового ринку транзитних перевезень, визначено фактори впливу на ринок транзитних та транспортних вантажоперевезень. Також проаналізовано стан сучасного ринку транзитних можливостей в сучасному світовому економічному просторі, а саме досліджено основні тендениії щэодо рівня транзитних можливостей за останні роки.

Встановлено, що існує ряд проблем, які негативно впливають на функиіонування ринку транзитних перевезень. а саме невирімені проблеми взаємодії між різними системами $i$ видами транспорту в транспортному ланцюгу $i$ недостатній розвиток сучасних логістичних систем - комбінованих, мультимодальних схем перевезення розвитку краӥн світу. Саме транзитні перевезення можуть надати нашій державі нові надходження зовнішніх коштів $i$ підвищити ї̈ економічний стан. Тому розвиток транзитного потенціалу - иче важлива складова у формуванні ефективної $i$ потужної економіки Украӥни.

Ключові слова: транзитний потенціал, експорт транспортних послуг, імпорт транспортних послуг, транзитні шляхи.

Целью статьи является комплексное исследование процессов формирования рынка транзитных перевозок Украины. Статья охватывает теоретико-методологические аспекты становления и развития потенциала транспортных транзитных грузоперевозок Украины. В статье рассмотрены теоретические аспекты формирования мирового рынка транзитных перевозок, определены факторы влияния на рынок транзитных и транспортных грузоперевозок. Также проанализировано состояние современного рынка транзитных возможностей в современном мировом экономическом пространстве, а именно исследованы основные тенденции уровня транзитных возможностей за последние годы.

Установлено, что существует ряд проблем, которые негативно влияют на функционирование рынка транзитных перевозок. а именно нерешенные проблемы взаимодействия между различными системами и видами транспорта в транспортной цепи и недостаточное развитие современных логистических систем - комбинированных, 
мультимодальных схем перевозки. развития стран мира. Именно транзитные перевозки могут предоставить нашему государству новые поступления внешних средств $и$ повысить ее экономическое положение. Поэтому развитие транзитного потенциала это важная составляющая в формировании эффективной и мощной экономики Украины.

Ключевые слова: транзитный потенциал, экспорт транспортных услуг, импорт транспортных услуг, транзитные пути.

The article is a comprehensive study of the formation transit market Ukraine. The article covers the theoretical and methodological aspects of the formation and development potential of transit cargo transportation Ukraine. In the article the theoretical aspects of the global market transit, the factors influencing the market and transit cargo transportation. Also analyzed the modern market of transit opportunities in today's world economy, namely the basic tendencies on the level of transit facilities in recent years.

Established that a number of problems that negatively affect the functioning of the transit market. namely the unresolved problems of interaction between different systems and modes in the transport chain and insufficient development of modern logistics systems - combined, multimodal transport schemes. developing countries. This transit can give our country a new flow of external funds and improve its economic situation. Therefore, the development of transit potential - is an important component in the formation of an effective and powerful economy of Ukraine. transit routes.

Keywords: transit potential, the export of transport services, transport services import,

Вступ. Для того щоб вийти 3 економічної кризи та тримати кращі позиції в економічному просторі країнам необхідно знаходити шляхи підвищення ефективності для кращого функціонування національної економіки. Використання території України, як транзитного потенціалу, і $\epsilon$ однією з можливостей не використовувати національний доход і покращити національну економіку нашої держави.

Значну кількість наукових праць присвячено формуванню та розвитку транзитних можливостей України в світовий економічний простір, серед них: 3. Бжезинского [5], К. Савченко [3], В. Зубенко [3], У. Бека [4], А. Новікова [2], Т. Маселко [1], М. Данько [3], С. Панченко [3] інші. Однак, ще залишаються не вирішеними ряд проблем: взаємодії між різними системами і видами транспорту в транспортному ланцюгу України та вдосконалення розвитку сучасних логістичних систем.

Постановка завдання. Основними цілями наукової статті є: оцінити обсяги транзитних перевезень територією України за останні роки, проаналізувати темпи зростання транзитних перевезень за видами транспорту, визначити обсяги експорту та імпорту товарів України та іï сусідніх держав.

Метою даної статті є розробка практичних рекомендацій та науковометодичних підходів щодо покращення транзитного потенціалу України в економічному просторі.

Методологія дослідження. Теоретичною та методологічною основою статті $є$ роботи вітчизняних і зарубіжних вчених в галузі транспортного потенціалу. Стаття грунтується на системному підході завдяки, чому $є$ 
можливість розглядати транзитний потенціал України в економічному просторі, а також оцінити реалізацію транспортного потенціалу та виявити причино-наслідкові зв'язки.

Результати дослідження. У сьогочасних умовах функціонування ринкової економіки, в силу геополітичного розташування України та іiї регіонів, характерної актуальності набувають питання ефективного використання їх транзитного потенціалу. Транзитний потенціал України визначає ii місце в системі міжнародних зв'язків і повинен ефективно реалізовуватися завдяки вигідному геоекономічному та геополітичному розташуванню. Оцінювання транзитних можливостей України в світовому економічному просторі $\epsilon$ невід'ємною складовою для покращення функціонування національної економіки.

Наша країна протягом всієї історії була центром та найзручнішим транспортним вузлом між Європою та Азією. Україна є сусідом 7 країн: Польщі, Словаччини, Угорщини, Румунії, Молдови, Росії, Білорусі. Тому доцільно буде розглянути оцінку транзитних можливостей України та іiі сусідів.

Транзитний потенціал України відіграє провідну роль в системі міжнародних зв'язків і сприяє розвиткові багатьох сфер національної економіки: будівництва, транспортного комплексу, промисловості, сфер послуг.

Транспортна система 3 iї вигіднішим геоекономічним і геополітичним розташуванням, опосередковує зовнішньоекономічні зв'язки країни на міжнародних транспортно-транзитних ринках. Її значення можна оцінити в загальному обсязі імпорту та експорту послуг.

Саме транзитні перевезення можуть надати нашій державі нові надходження зовнішніх коштів і підвищити іiі економічний стан. Тому розвиток транзитного потенціалу - це важлива складова у формуванні ефективної і потужної економіки України.

Якщо розглядати транзитний транспортний потенціал як економічну категорію, то він характеризує не тільки здатність здійснення міжнародних перевезень через територію, а і повинен забезпечувати комплексний розвиток на цій основі.

Взагалі, під визначенням транзит розуміють - перевезення вантажів або пасажирів з однієї держави до іншої або з одного пункту до іншого через проміжні пункти. Загальне поняття транзиту передбачає різні перевезення та наявність пунктів відправлення, проміжного та кінцевого. Закон України "Про транзит вантажів" звужує поняття транзиту до міжнародних перевезень через територію України, оскільки визначає транзит вантажів як "перевезення транспортними засобами транзиту транзитних вантажів під митним контролем через територію України між двома пунктами або в межах одного пункту пропуску через державний кордон України"[7].

В сучасний умовах інтеграційні зв'язки потребують інтенсивного розвитку послуг транспорту, зокрема міжнародних пасажирських перевезень. В Україні майже недослідженою залишається роль транспортної складової в 
забезпеченні міжнародної інтеграційної взаємодії. Посилення інтеграційного співробітництва через отримання високоякісних транспортних послуг від іноземних постачальників і проникнення на зовнішні ринки перевезень $\epsilon$ важливим елементом національного розвитку [8].

Проводячи аналіз можливостей видів транспорту слід зазначити, що залізниці України є не тільки вагомою частиною народногосподарського комплексу України, вони також є значним транзитним коридором між Сходом і Заходом. Сьогодні вони безпосередньо межують і взаємодіють із залізницями Росії, Білорусі, Молдови, Польщі, Румунії, Словаччини, Угорщини, забезпечують роботу по 56 міжнародним залізничних переходах, а також обслуговують 18 українських морських портів ЧорноморськоАзовського басейну, а також річок Дніпра і Дунаю.

Експлуатаційна довжина залізничних колій України загального користування у 2015 році становила 20,94 тис. км у тому числі електрифікованих 9,97 тис. км (без врахування тимчасово окупованої території Автономної Республіки Крим, м. Севастополя та частини зони проведення антитерористичної операції). По яких відправлено 294301,2 тис. тон та перевезено 349994,0 тис. тон. вантажу.

Щодо обсягів транзитних перевезень територією України, то протягом минулих шести років показники вантажообігу зазнали незначних змін (табл. 1). У 2015 році на трубопровідному вантажообіг скоротився в порівнянні 3 2010 на 36,6\% або на 56205,1 тис. т, залізничний вантажообіг скоротився на $19,2 \%$ або на $82,902,2$ тис. т, морський вантажообіг скоротився на $19,1 \%$ або на 776,2 тис. т, автомобільний вантажообіг скоротився на $12,6 \%$ або на 147614,8 тис. т, річковий вантажообіг скоротився на $54,9 \%$ або на 3834 тис. т, авіаційний вантажообіг скоротився на 21,4\% або на 18,8 тис. т.

Збільшення обсягів товарообігу до країн $\mathrm{C,} \mathrm{Азії} \mathrm{та} \mathrm{СНД,} \mathrm{через}$ активізацію інтеграційних процесів. Це пов'язано з тим що географічне положення нашої держави дає змогу не тільки ефективно вести торгівлю, а i перевозити вантажі різними видами транспорту між країнами Азії, СНД та ЄС. Між нашою країною та країнами Азії, Америки відбулося скороченням вантажообігу. Це відбулось через світову тенденцію зменшенням вантажних перевезень повітряним та морським транспортом, через зріст тарифних ставок[10].

Таблиияя 1

Обсяги транзитних перевезень територією України за 2010-2015 pp., тис. т. (складено авторами на основі [6])

\begin{tabular}{|l|l|l|l|l|l|l|}
\hline \multicolumn{1}{|c|}{ Транспорт } & \multicolumn{1}{c|}{$\mathbf{2 0 1 0}$} & \multicolumn{1}{c|}{$\mathbf{2 0 1 1}$} & \multicolumn{1}{|c|}{$\mathbf{2 0 1 2}$} & \multicolumn{1}{c|}{$\mathbf{2 0 1 3}$} & \multicolumn{1}{c|}{$\mathbf{2 0 1 4}$} & \multicolumn{1}{c|}{$\mathbf{2 0 1 5}$} \\
\hline Трубопровідний & 153436,6 & 154971,2 & 128439,8 & 125941,1 & 99679,5 & 97231,5 \\
\hline Залізничний & 432897,0 & 469308,1 & 457454,5 & 443601,5 & 386276,5 & 349994,8 \\
\hline Морський & 4067,8 & 4145,6 & 3457,5 & 3428,1 & 2805,3 & 3291,6 \\
\hline Автомобільний & 1168218,8 & 1252390,3 & 1259697,7 & 1260767,5 & 1131312,7 & 1020604,0 \\
\hline Річковий & 6989,5 & 5720,9 & 4294,7 & 2840,5 & 3144,8 & 3155,5 \\
\hline
\end{tabular}




\begin{tabular}{|c|l|l|l|l|l|l|}
\hline Авіаційний & 87,9 & 92,1 & 122,6 & 99,2 & 76,6 & 69,1 \\
\hline \multicolumn{2}{|c|}{ З даного графіга вида, } \\
\hline
\end{tabular}
транспортних перевезень спостерігаються у 2012 році в авіаційних транспортних перевезеннях, через Євро-2012. У 2015 році в порівнянні з 2010 роком зменшилися обсяги транзиту: на трубопровідному і залізничному та автомобільному у 2.2 рази; морському у 1,1 рази. Втрачено обсяги транзиту річкового транспорту більше чим на $50 \%$ (рис. 1 ).

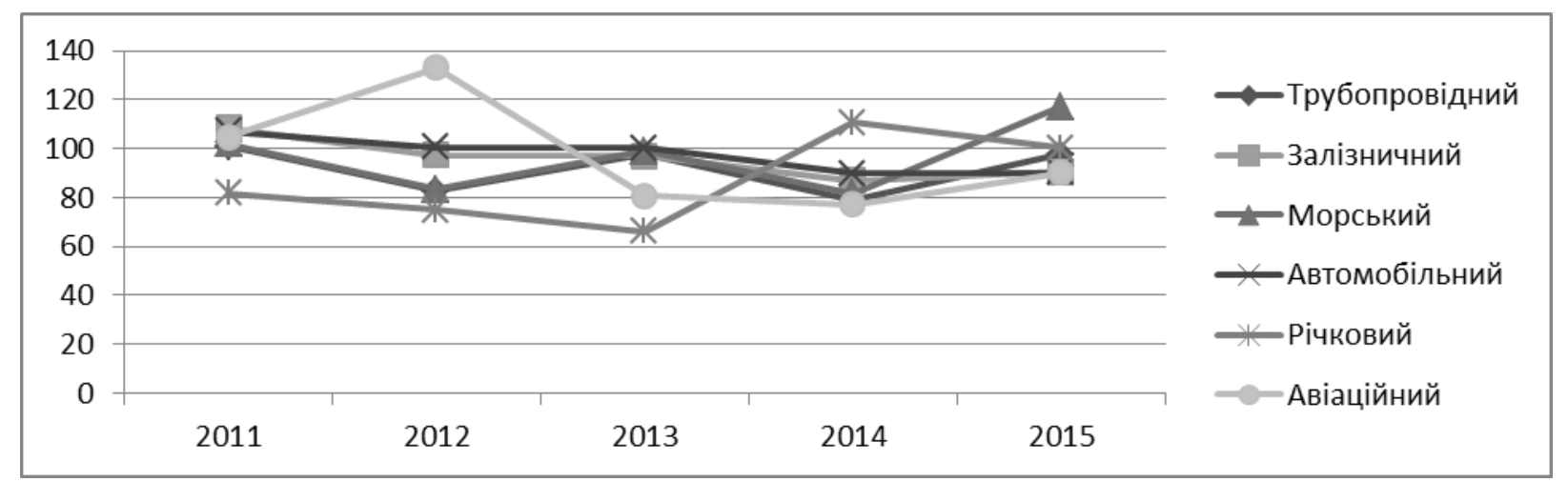

Рис. 1. Темпи зростання транзитних перевезень за видами транспорту

В економічній системі Україні експорт та імпорт транзитних перевезень займають важливе значення. Оскільки ВВП України експорт та імпорт формує по 50\%, тому економіка нашої держави пов'язана 3 зовнішньоторговельним оборотом більш ніж на 100\%. Значний обсяг вантажопотоків проходить у напрямку Схід-Захід, оскільки Україна 3 країнами СНД близько $50 \%$ формує експортних та імпортних зовнішньоекономічних товаропотоків i на це припадає левова частина транзиту $-90 \%$.

Значними групами експортних (рис. 2.) вантажів є: машини, обладнання та механізми; електротехнічне обладнання 3940855,8 тис дол. США, недорогоцінні метали та вироби 3 них 9470719,2 тис дол. США, продукція хімічної та пов'язаних з нею галузей промисловості 183464,9 тис дол. США, деревина і вироби з деревини 1107197,0 тис дол. США, продукти рослинного походження 7971492,5 тис дол. США, жири та олії тваринного або рослинного походження 3299799,1 тис дол. США, мінеральні продукти 3099490,6 тис дол. США, готові харчові продукти 2468418,0 тис дол. США та ін. 


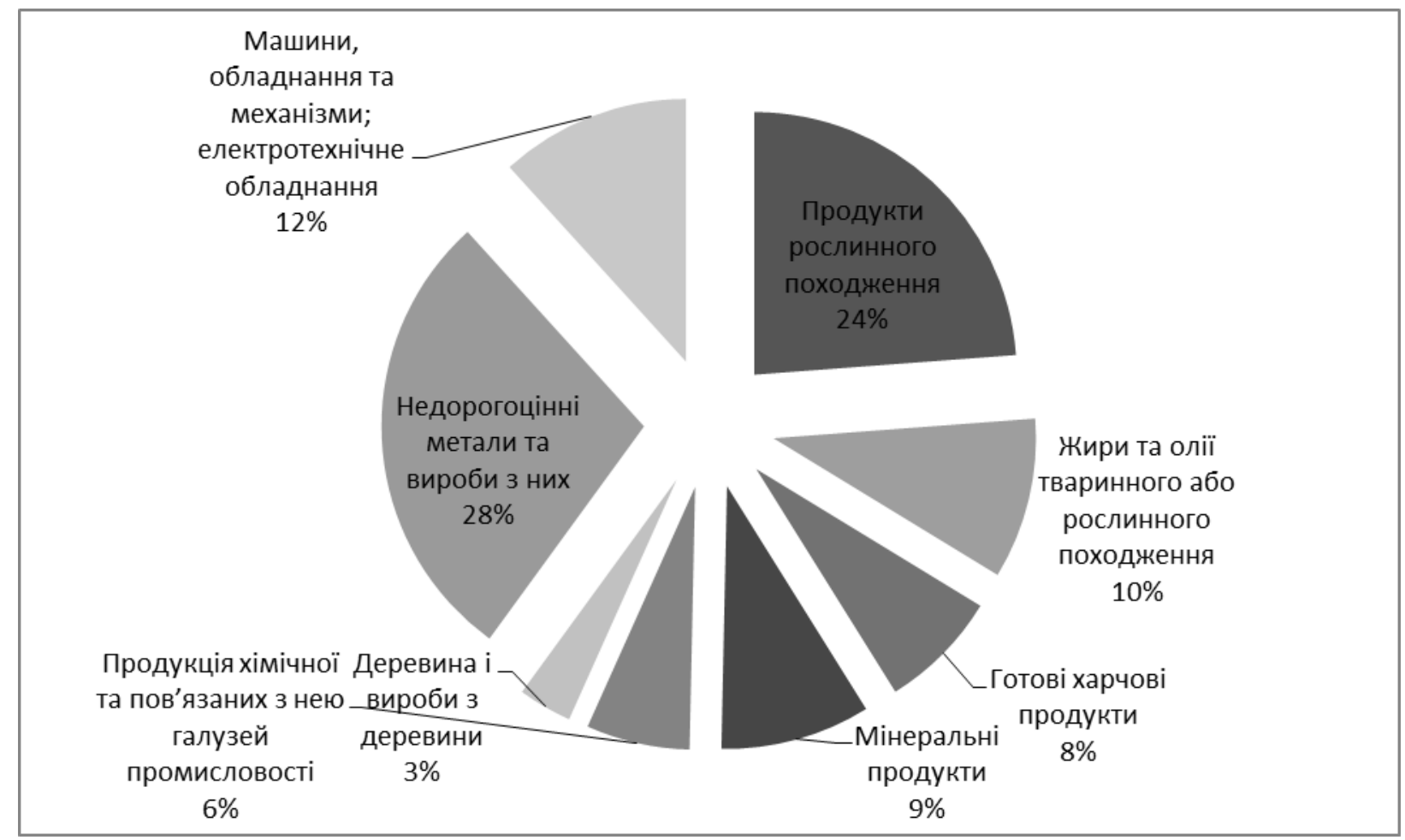

Рис. 2. Експорт транзитних перевезень 2015 р. (складено авторами на основі статистичних даних [6])

Щодо структури українського експорту, то протягом багатьох років його більшу частину являє складова сировинна. Першорядними товарними позиціями експорту України $є$ зернові культури, залізорудна сировина та металопродукція. Орієнтованість на вивезення сировинних ресурсів $\epsilon$ основним чинником нестабільності експортних позицій України, оскільки сировинні ринки тісно пов'язані зі світовою кон'юнктурою і не є сталими ні за обсягами, ані за цінами.

В експорті транзитних перевезень за останні роки не зазнали значних змін, а саме недорогоцінні метали та вироби з них - $28 \%$ я яких 21,2 \% чорні метали. Продукти рослинного походження - $24 \% 3$ яких 15,9 \% зернові культури. Машини, обладнання та механізми; електротехнічне обладнання $12 \% 3$ яких 5,2 \% електричні машини, 5,1\% реактори ядерні,котли та машини. Жири та олії тваринного або рослинного походження - $10 \% 3$ яких 6,5 \% готові харчові продукти. Мінеральні продукти - $9 \% 3$ яких 5,8 \% руда, шлак та зола. Готові харчові продукти $-8 \%$ я яких 2,6 \% залишки і відходи харчової промисловості. Продукція хімічної та пов'язаних 3 нею галузей промисловості - 6 \% з яких 2,5 \% продукти неорганічної хімії.

Через територію України імпортують наступні групи вантажів(рис. 3.): готові харчові продукти 1607736,9 тис дол. США, текстильні матеріали та текстильні вироби 1414595,1 тис дол. США, засоби наземного транспорту, літальні апарати, плавучі засоби 1743638,6 тис дол. США, машини, обладнання та механізми; електротехнічне обладнання 6273379,8 тис дол. США, недорогоцінні метали та вироби з них 2004239,5 тис дол. США, полімерні матеріали, пластмаси та вироби з них 2646219,1 тис дол. США, 
продукція хімічної та пов’язаних з нею галузей промисловості 5009163,1 тис дол. США та ін.

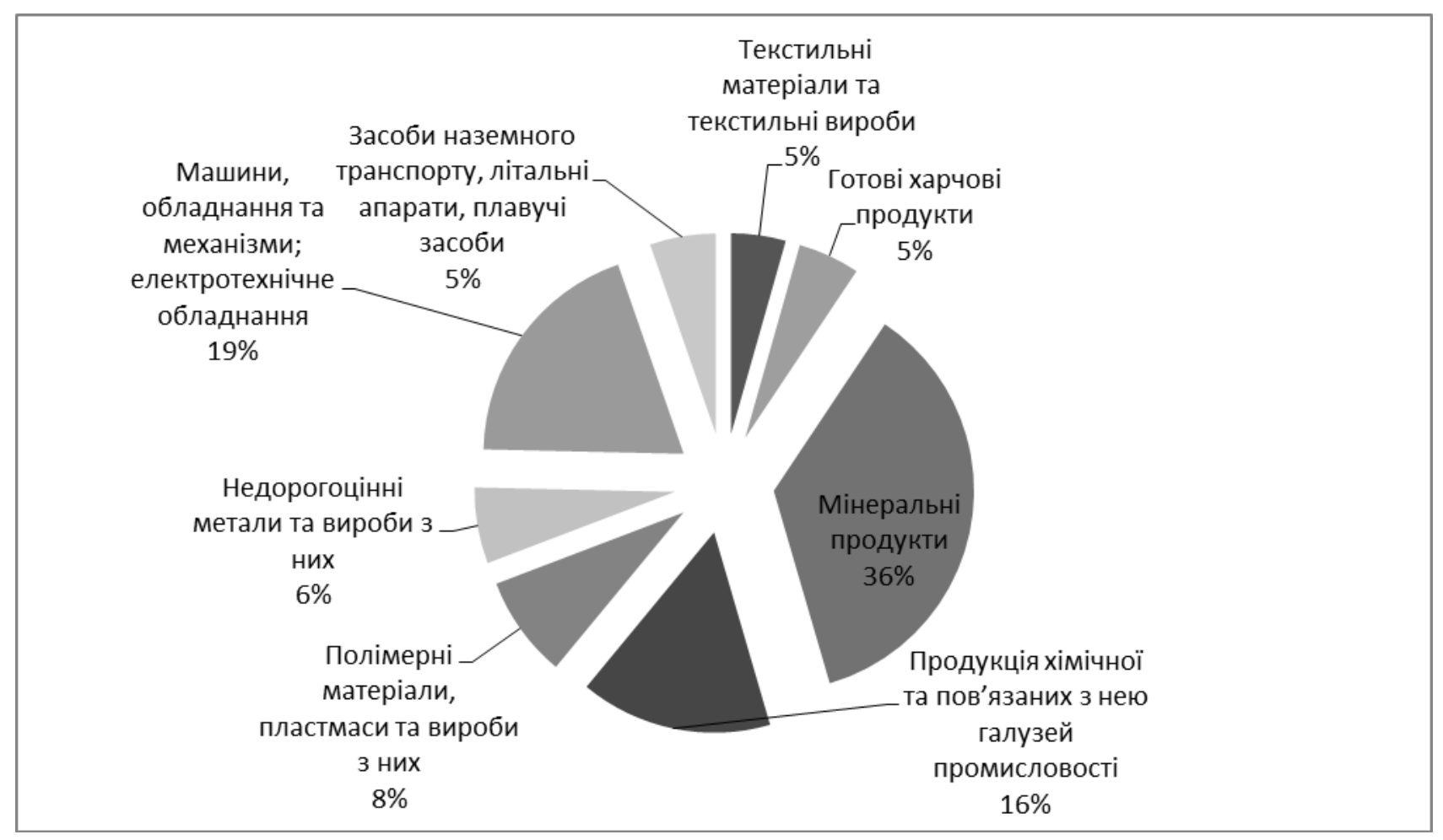

Рис. 3. Імпорт транзитних перевезень 2015 р. (складено авторами на основі статистичних даних [6])

Імпортні товаропотоки нашої держави на відміну від експортних товаропотоків займає автомобільний транспорт 50,5 \%, потім залізничний 27,8 \%. До України найбільші обсяги надходять з Польщі та Німеччини. В імпорті транзитних перевезень за останні роки не зазнали значних змін, а саме мінеральні продукти займають питому вагу - 36 \% 3 яких 29 \% це палива мінеральні, нафта і продукти іiі перегонки. Продукція хімічної та пов’язана 3 нею галузей промисловості - 16 \% з яких 3,6 \% це фармацевтична продукція. Машини,обладнання та механізми, електротехнічне обладнання $19 \%$ я яких 9,5 \% це реактори ядерні, котли та машини.

Найбільший обсяг всіх перевезень припадає на транзит (табл. 2), даліекспорт i найменше на імпорт. В транзиті та імпорті переважає трубопровідний і залізничний, в експорті - залізничний транспорт.

Структура транзитних вантажоперевезень України надає перевагу лише двом видам транспорту залізничного та трубопровідного, що призводить до уразливості транзитного пакету України. Але завдяки своєму географічному розташуванню, транзит $є$ невичерпаним ресурсом для отримання коштів державою.

У структурі міжнародних вантажопотоків транзит становить 40,8\%, які проходять через Українські кордони. Це обумовлено тим що в нашій країні існують наявні потужності у морських портах 3 переробки транзитних 
вантажів, та транзиту трубопровідним транспортом сировини вуглеводневої Росією та ЄС у п’ять разів більший, ніж через нашу країну. Вантажі які перевозяться річковим транспортом скоротилися суттєва, найбільші 3 яких: 3 Албанії, Канади до Росії та Казахстану та ін..

Таблиия 2

Обсяги експорту та імпорту товарів України та іiї сусідніх держав, тис. дол. США (складено авторами на основі статистичних даних [6])

\begin{tabular}{|l|l|l|l|l|l|}
\hline \multirow{2}{*}{ Країна } & \multicolumn{2}{|c|}{ Експорт } & \multicolumn{3}{c|}{ Імпорт } \\
\cline { 2 - 6 } & $\begin{array}{c}\text { Країна } \\
\text { призначення }\end{array}$ & $\begin{array}{c}\text { Країна, що } \\
\text { торгує }\end{array}$ & $\begin{array}{c}\text { Країна } \\
\text { походження }\end{array}$ & $\begin{array}{c}\text { Країна } \\
\text { відправлення }\end{array}$ & $\begin{array}{c}\text { Країна,що } \\
\text { торгує }\end{array}$ \\
\hline Польща & 1977329,6 & 1462749,7 & 2324048,2 & 3279022,4 & 2484637,2 \\
\hline Словаччина & 468528,8 & 293689,8 & 346331,1 & 359163,3 & 284323,0 \\
\hline Румунія & 569947,1 & 297830,9 & 318202,3 & 376858,2 & 202816,6 \\
\hline Молдова & 524294,0 & 450271,1 & 41242,4 & 49875,0 & 47988,2 \\
\hline Росія & 4827717,9 & 4397700,4 & 7492724,5 & 5585315,1 & 5674429,1 \\
\hline Білорусь & 870696,4 & 636549,0 & 2449145,5 & 2481356,5 & 1367389,1 \\
\hline Угорщина & 909721,0 & 635867,5 & 1608536,1 & 1375910,4 & 1759378,0 \\
\hline
\end{tabular}

Щоб краще використовувати весь транзитний потенціал України, потрібно вирішити ряд проблем розвитку транспортно-транзитної інфраструктури. В першу чергу це побудова автомагістралей та митних переходів. Для автомобільних перевезень це європейський напрямок, для залізничних - країни СНД.

В 2014 році було відкрито на кордоні України та Польщі міжнародний пункт пропуску «Угринів-Долгобичув». Після проведення Євро-2012 він був закритий, побудовано 14 смуг руху. На сьогодні він $є$ найсучаснішим пунктом пропуску на кордоні України та країн $\mathrm{CC}$, але працює поки у тестовому режимі по одній смузі в кожен бік, на жаль біля цього переходу залишається не розвинутою транспортна інфраструктура.

Деякі пункти пропуску через державний кордон України для здійснення ввезення товарів з Російської Федерації в режимі транзиту було закрито. 3 січня 2016 р. була затверджена постанова Кабінету міністрів України в якій вказано пункти пропуску на кордоні з РФ:

1) для автомобільного сполучення - Просяне, Танюшівка, Плетинівка, Гоптівка, Велика Писарівка, Юнаківка, Катеринівка, Бачівськ, Грем'яч, Сеньківка; 
2) для залізничного сполучення - Лантратівка, Тополі, Козача Лопань, Зернове.

Також наведено пункти пропуску на кордоні з Республікою Білорусь:

1)для автомобільного сполучення - Доманове, Сеньківка, Нові Яриловичі, Славутич, Виступовичі, Городище, Дольськ, Пулемець;

2) для залізничного сполучення - Неданчичі, Щорс, Горностаївка, Удрицьк, Заболоття, Виступовичі [9].

За для збільшення експортно-імпортних вантажопотоків в Україні $\epsilon$ певні труднощі, вони пов'язані з необхідністю залучення у розвиток транспортної системи України інвестицій. Такими проблемами є [11]:

- Автомобільний транспорт: 1) українські дороги не відповідають стандартам якості європейських доріг (швидкість, безпека, надійність та ін.); 2) матеріально-технічна база за якою здійснюють обслуговування автомобільної транспортної мережі є застарілою.

- Повітряний транспорт: 1) недостатнє фінансування перебудови та будівництва предметів авіаційної інфраструктури, 2) не достатньо комплектації парку літаків.

- Залізничний транспорт: 1) зниження експлуатаційної характеристики залізниці через те що ширина європейської колії відрізняється від нашої, 2) зношеність основних фондів.

- Трубопровідний транспорт: майже всі маршрути орієнтовані на транзит газу та нафти тільки з Росією.

- Водний транспорт: 1) застаріла портова інфраструктура, 2) мала тоннажність та застарілість кораблів, портового обладнання.

Висновки. Проаналізувавши наведені тенденції, що склалися на транзитному ринку транспортних перевезень, можна відмітити такі основні тенденції:

Росія ціле направлено знищує руками терористів і найманців ряд транспортних шляхів на сході держави та будує свої залізничні і дорожньотранспортні транзитні шляхи в обхід України. Використовуючи Митний союз перенаправляє вантажі в обхід території України на найважливіший напрям Європа-Азія, застосовуючи спрощені митні процедури і зменшуючи тарифи. Також вантажі російського походження перевантажуються у портах України на порт РФ.

Час, вартість та безпека доставки - три умови, які не витримують митні органи України. Недостатня швидкість перевезень, відсутність гарантій на збереження вантажів, високі тарифи , які збільшуються та затримка вантажів перевіряючими органами. Відсутність уваги до потреб клієнтів з боку держаних транспортних служб та органів. Тому зростає конкуренція з боку держав-сусідів, які залучають традиційні для України і нові вантажопотоки.

Незадовільний стан доріг, 90\% яких потребують ремонту, середня швидкість на яких в декілька разів менша, ніж в європейських країнах, наявність вузьких місць в залізничній структурі в порівнянні 3 Росією і Білоруссю, які швидко розбудовують свої транспортні шляхи 3 метою 
приєднатися до міжнародної транспортної мережі є потужною конкуренцією України.

Отже, для покращення та адаптації до транс'європейської залізничної мережі необхідно для українських залізниць розробити та гармонізувати нормативно-правову базу та заходи державної підтримки до міжнародноправових норм. Також було б доцільно наблизити технологічні та технічні стандарти до європейських, зблизити рухомий склад до європейської транспортної системи.

Щодо автотранспортних вантажних перевезень, то потрібно посилити контроль за станом доріг, врегулювати правовідносини при перевезенні вантажів. Створення мережі логістичних центрів. Обов'язково дотримуватися екологічних стандартів та нормативів у галузі транспорту. Стимулювання розвитку експорту транспортних послуг та більш ефективно використовувати транзитний потенціал країни.

Для портів України потрібно залучати приватний капітал, через те що недостатнє фінансування з боку держави. Створити нові методи управління та покращити систему прийняття рішень, щоб не було проблеми планування та реалізації проектів. Також через неефективне управління потрібно переймати в інших державах кращі практики управління портами. Покращити якість обслуговування та нові вантажопотоки.

Наукова новизна проведеного дослідження полягає в запропонованому системному підході до аналізу причин і наслідків організації сучасної моделі транспортних перевезень в Україні та транзитного потенціалу України в економічному просторі. Практична значущзість дослідження полягає у використанні методів управління та прийняття рішень, на основі виявлених причинно-наслідкових зв'язків 3 можливостями сучасного функціонування системи транспортних перевезень та транспортного потенціалу України, в удосконаленні організації інвестиційної діяльності в транспортній системі України.

\section{Література:}

1.Маселко Т. Є. Проблеми управління транспортно-логістичними системами України та перспективи розвитку в контексті європейської інтеграції / Т. Є. Маселко, С. Г. Шевченко. Режимдоступу

http://www.nbuv.gov.ua/portal/chem_biol/nvnltu/17_2/301_Maselko_17_2.pdf

2. Новікова А. М. Україна в системі міжнародних транспортних коридорів / А. М. Новікова. -К. : НІПМБ, 2003. - 494 с.

3. Проблеми міжнародних транспортних коридорів та єдиної транспортної системи України : тези доповідей за матеріалами сьомої наук.-практ. міжнар. конф. (30 травня - 4 червня 2011 p., смт. Коктебель). - Режим доступу :http://www.nbuv.gov.ua/portal/Natural/Vetp/2011_34/11dtdzep.pdf

4. Бек У. Что такое глобализация? Ошибки глобализма - ответы на глобализацию / У.Бек .- пер. с нем. А. Григорьева, В. Седельника; общ. ред. и послесл. А. Филиппова. М.: Прогресс-Традиция, 2001. - 304 с.

5. Бжезинский 3. Великая шахматная доска. Господство Америки и его геостратегические императивы / З. Бжезинский. - М.: Междунар. отношения, 1999. - 256 c. 
6. Державний комітет статистики. - Режим доступу : https://ukrstat.org/uk/operativ/operativ2013/zd/eit_zk/eit_zk_0115_u.htm

7. Про транзит вантажів:ЗаконУкраїни від 20 жовтня 1999 p. №1172XIV // Відомості Верховної Ради України.- 1999. - ст. 446 (із змінами та доповненнями).

8. Бутко М.П. Інтеграційна стратегія розвитку транзитно-транспортної системи України на сучасному етапі / М. П. Бутко [Електронний ресурс].- Режим доступу: http://intkonf.org/boykomv-integratsiyna-strategiya-rozvitku-tranzitno-transportnoyi-sistemiukrayini-na-suchasnomuetapi/.

9. Постанова №20 Про затвердження переліку пунктів пропуску через державний кордон України, через які здійснюється ввезення товарів в режимі транзиту [Електронний pecypc]. - 20. - Режим доступу до ресурсу: http://zakon5.rada.gov.ua/laws/show/20-2016$\% \mathrm{D} 0 \% \mathrm{BF}$.

10. Мировая транспортная система: структура и развитие.Официальный сайт журнала «Бизнес-Центр» [Электронный ресурс] - Режим доступа: http://biznesdays.ru/mirovayatransportnaya-sistema-struktura-i-razvitie.html.

11. Официальный сайт: Международный транспортный форум [Электронный pecypc] // Режим доступа: http://www.internationaltransportforum.org. 